\title{
EFFECTS OF ISOSORBIDE DINITRATE ON EXERCISE CAPACITY IN CARDIAC PATIENTS -Relationship Between Oxygen Uptake Responses and Hemodynamic Effects-
}

\author{
Akira Koike, M.D., Haruki Itoh, M.D., Mayumi Doi, M.D. \\ Koichi Taniguchi, M.D., Fumiaki Marumo, M.D., Isao Umehara, M.D.* \\ and Michiaki Hiroe, M.D***
}

\begin{abstract}
Acute effects of oral isosorbide dinitrate on exercise capacity were evaluated in 14 patients with chronic heart disease measuring the anaerobic threshold and left ventricular function during exercise. A symptom-limited exercise test was performed on a bicycle ergometer with work rates increased by $1 \mathrm{~W}$ every 6 seconds. Left ventricular function was continuously monitored with a computerized cadmium telluride detector following the intravenous injection of technetium-labeled red blood cells. Thirty minutes after the control exercise test, patients were given isosorbide dinitrate, $5 \mathrm{mg}$ orally. The second exercise test was performed 30 min later. Isosorbide dinitrate improved the anaerobic threshold from $715.4 \pm 172.9$ to $774.9 \pm 173.5 \mathrm{ml} / \mathrm{min}(\mathrm{p}<0.01)$ and ejection fraction at peak exercise from $36.7 \pm 11.6$ to $39.9 \pm 12.3 \%(\mathrm{p}<0.05)$. However, there was no significant change in maximum work rate or peak oxygen uptake. Those patients for whom isosorbide dinitrate resulted in a $10 \%$ or greater improvement in the anaerobic threshold had both higher pre-treatment ejection fractions and greater increases in peak exercise ejection fraction following isosorbide dinitrate. Measurements of the anaerobic threshold and left ventricular function during exercise may be useful in the evaluation of the efficacy of vasodilators in cardiac patients.
\end{abstract}

$\mathbf{N}^{\prime}$ ITRATES have been used widely for the therapy of left ventricular failure, as well as angina pectoris, because vasodilator drugs usually reduce left ventricular end-diastolic pressure and increase cardiac output at rest in patients with heart failure -4 Although there are many reports on the acute and chronic hemodynamic effects of nitrates, $2,-11$ especially in the resting state, some investigators have reported that acute

Key words:

The anaerobic threshold

Cadmium telluride detector

Vasodilator therapy nitrate therapy does not increase exercise capacity in heart failure $5,6,9$ Although intermittent nitrate therapy has been recommended to prevent the build-up of tolerance to its long term hemodynamic effects ${ }^{12,13}$ the acute effect of isosorbide dinitrate on exercise capacity in patients with heart failure remains uncertain.

It has been reported that the anaerobic threshold can be used to identify the exercise capacity of heart failure patients noninvasively ${ }^{4}$ A number of investigators have used the anaerobic threshold measurements to estimate the degree of cardiovascu-

(Received January 16, 1990; accepted February 23, 1990)

Second Department of Internal Medicine, Tokyo Medical and Dental University; * Department of Radiology, Tokyo Medical and Dental University; ${ }^{* *}$ Department of Radiology, Tokyo Women's Medical College; Tokyo, Japan

Mailing address: Akira Koike, M.D., Second Department of Internal Medicine, Tokyo Medical and Dental University, 5-45 Yushima 1-Chome Bunkyo-ku, Tokyo 113, Japan 
lar impairment ${ }^{15-18}$ and effectiveness of therapy 19,20 In general, the anaerobic threshold correlates well with the functional status of patients with heart failure ${ }^{16}$

Recently, the development of exercise radionuclide angiography has made possible the measurement of ejection fraction during exercise and expanded the diagnostic potential of exercise testing? $21-23$

In the present study, we examined the acute effects of oral isosorbide dinitrate on exercise capacity in patients with chronic heart disease by measuring the anaerobic threshold, and comparing any change in the anaerobic threshold with the pattern of left ventricular function measured by radionuclide angiography during exercise.

\section{METHODS}

\section{Patient population}

Fourteen patients with chronic heart disease participated in this study (Table I). Ten patients were men and 4 patients were women, aged 47 to 72 years (mean age 61.5 years). New York Heart Association functional classification was as follows: 2 patients in class I, 11 in class II, and 1 in class III. The etiology of the cardiac lesion was ischemic heart disease with previous myocardial infarction in five, ischemic heart disease without documented infarction in 3 , valvular heart disease in 5, and dilated cardiomyopathy in 1 . Eight patients had a sinus rhythm and 6 had atrial fibrillation. The study excluded patients with pure mitral stenosis or aortic stenosis. None of the patients had a myocardial infarction within 2 months preceding enrolment in the study. All medications were withheld for $24 \mathrm{~h}$ before the study.

\section{Exercise testing}

An electromagnetically-braked cycle ergometer (Siemens-Elema 930B with a ramp slope controller) was used for exercise testing. After a 4 min rest on the ergometer, exercise began with a 4 min warm-up at $20 \mathrm{~W}$, $60 \mathrm{rpm}$, followed by $1 \mathrm{~W}$ incremental loading every $6 \mathrm{sec}$ in the upright position. The ECG and heart rate were monitored throughout the test by a 12-lead electrocardiogram (Stress System ML-8000, Fukuda Denshi, Tokyo). Cuff blood pressure was also measured every minute with an automatic indirect manometer (Stress Test Blood Pressure Monitor STBP-680F, Collin Denshi, Aichi). Cardiac output during a fourminute rest period preceding exercise was measured by the dye dilution method with indocyanine green ${ }^{24}$ using an ear photoelectric transducer, the output of which was analyzed by a special purpose computer (Cardiac Output Computer MLC-4200, Nihon-Kohden, Tokyo). The end-point of exercise for all the patients was leg fatigue or dyspnea. No patient experienced chest pain during exercise.

Thirty minutes after the control exercise test, patients were given isosorbide dinitrate, $5 \mathrm{mg}$ orally. The second exercise test was performed $30 \mathrm{~min}$ later.

\section{Expired gas analysis}

Subjects breathed through a mask (from which expired gas was collected) at rest and during exercise. Oxygen uptake $\left(\mathrm{VO}_{2}\right)$, carbon dioxide output $\left(\mathrm{VCO}_{2}\right)$, and the rate of respiratory air flow were measured by a computerized system (Aerobic Processor 391, Nihon Denki Sanei, Tokyo), consisting of a mixing chamber (2.5 liters), a polarograph oxygen analyzer, infra-red carbon dioxide analyzer, and hot wire spirometer. Gas exchange and flow measurements were corrected for ambient temperature, barometric pressure and water vapor. The system was carefully calibrated before each study. From these measurements, $\mathrm{VO}_{2}$, $\mathrm{VCO}_{2}$ and minute ventilation $(\dot{\mathrm{VE}})$ were calculated every 10 seconds. These variables, along with the gas exchange ratio $\left(\dot{\mathrm{VCO}}_{2} / \mathrm{VO}_{2}\right)$, and the ventilatory equivalents for $\mathrm{O}_{2} \quad\left(\dot{\mathrm{VE}} / \mathrm{VOO}_{2}\right)$ and $\mathrm{CO}_{2}$ $\left(\dot{\mathrm{VE}} / \mathrm{VCO}_{2}\right)$, were displayed on a monitor during exercise testing using a personal computer (NEC PC-9801).

The anaerobic threshold was determined primarily by the $\mathrm{V}$-slope $\operatorname{method}^{25}$ in addition to the following conventional criteria ${ }^{26,27}$ : 1) $\mathrm{VE} / \mathrm{VO}_{2}$ increases after being stable or decreasing, while $\mathrm{VE} / \mathrm{VCO}{ }_{2}$ remains constant or is decreasing; 2) the gas exchange ratio, which was stable or slowly rising, begins to increase more steeply.

\section{Monitoring of left ventricular function}

The methods utilized in this study have 
TABLE I PHYSICAL CHARACTERISTICS, PHYSIOLOGICAL DATA, AND CARDIAC DIAGNOSIS OF SUBJECTS

\begin{tabular}{|c|c|c|c|c|c|c|c|c|}
\hline$P t$ & $\begin{array}{l}\text { Age } \\
(y r)\end{array}$ & Sex & $\begin{array}{c}\text { Weight } \\
(k g)\end{array}$ & NYHA & Rhythm & Cardiac lesion & $\underset{(\mathrm{ml} / \mathrm{min})}{\stackrel{A T}{\text { ontrol }}}$ & $\begin{array}{l}\underset{\text { after ISDN }}{(\mathrm{ml} / \mathrm{min})} \\
\end{array}$ \\
\hline \multicolumn{9}{|c|}{ Group 1 (\% change of $\underline{A T} \geq 10 \%)$} \\
\hline 1 & 69 & $M$ & 53.0 & 2 & $N S R$ & $C A D(O M I)$ & 510 & 618 \\
\hline 2 & 62 & $M$ & 71.0 & 2 & $N S R$ & $C A D$ & 846 & 956 \\
\hline 3 & 72 & $M$ & 52.0 & 2 & $N S R$ & $C A D$ & 588 & 704 \\
\hline 4 & 59 & $M$ & 52.0 & 1 & $N S R$ & $C A D$ & 743 & 863 \\
\hline 5 & 64 & $F$ & 51.0 & 2 & $N S R$ & $C A D(O M I)$ & 731 & 849 \\
\hline 6 & 47 & $F$ & 50.0 & 2 & $A F$ & $M S R, T R$ & 508 & 592 \\
\hline 7 & 59 & $M$ & 58.0 & 2 & $A F$ & $D C M$ & 825 & 912 \\
\hline$M E A N$ & 61.7 & & 55.3 & 1.9 & & . & 678.7 & $784.9^{*}$ \\
\hline $\pm S D$ & 7.5 & & 6.8 & 0.4 & & & 132.1 & 134.8 \\
\hline \multicolumn{9}{|c|}{ Group 2 (\% change of $\underline{A T}<10 \%)$} \\
\hline 8 & 63 & $F$ & 49.0 & 2 & $N S R$ & $C A D(O M I)$ & 530 & 502 \\
\hline 9 & 55 & $F$ & 47.5 & 2 & $A F$ & $M S R, T R$ & 468 & 491 \\
\hline 10 & 59 & $M$ & 56.5 & 2 & $N S R$ & $C A D(O M I)$ & 975 & 918 \\
\hline 11 & 59 & $M$ & 66.0 & 2 & $A F$ & $M S R, A R$ & 932 & 1007 \\
\hline 12 & 64 & $M$ & 55.0 & 3 & $A F$ & $A S R, T R$ & 638 & 647 \\
\hline 13 & 68 & $M$ & 57.0 & 1 & $N S R$ & $C A D(O M I)$ & 981 & 992 \\
\hline 14 & 61 & $M$ & 56.0 & 2 & $A F$ & $M S R, T R, P R$ & 741 & 797 \\
\hline$M E A N$ & 61.3 & & 55.3 & 2.0 & & & 752.1 & 764.9 \\
\hline $\pm S D$ & 3.9 & & 5.6 & 0.5 & & & 199.2 & 204.5 \\
\hline \multicolumn{9}{|c|}{ Group $1+$ Group 2} \\
\hline$M E A N$ & 61.5 & & 55.3 & 1.9 & & & 715.4 & $774.9 \#$ \\
\hline $\pm S D$ & 6.0 & & 6.3 & 0.5 & & & 172.9 & 173.5 \\
\hline
\end{tabular}

Subjects were divided into two groups (group 1 and 2) according to the percent change of the anaerobic threshold $(A T)$.

$A F=$ atrial fibrillation; $A R=$ aortic regurgitation; $A S R=$ aortic stenoregurgitation; $C A D=$ coronary artery disease; $D C M=$ dilated cardiomyopathy; ISDN=isosorbide dinitrate; $M S R=$ mitral stenoregurgitation; $N S R=$ normal sinus rhythm; NYHA $=$ New York Heart Association functional classification; OMI $=$ old myocardial infarction; $P R=$ pulmonary regurgitation; $T R=$ tricuspid regurgitation.

${ }^{*} p<0.001 v s$. corresponding control data. $\# p<0.01 \mathrm{vs}$. corresponding control data.

been reported previously.2 A computerized cardiac monitoring system (RRG-607, Aloka Co. LTD., Tokyo) was employed for continuous monitoring of left ventricular function. This system is composed of a cadmium telluride detector A-116 (Radiation Monitoring Devices, Boston MA), a preamplifier unit, a portable data acquisition unit, and a central processing unit (NEC personal computer PC-9801). After the patient's red blood cells were labeled with $30 \mathrm{mCi}$ of technetium- $99 \mathrm{~m}$ by the semi-in vivo method, the cadmium telluride detector was positioned over the left ventricular region with a vest which was specially designed to hold the detector in place. The left ventricular region of interest was chosen as the position with the maximal ratio of stroke counts (end-di- astolic counts minus end-systolic counts) to average counts (end-diastolic counts plus end-systolic counts divided by 2$)^{29}$ Care was taken to avoid the right ventricle, left atrium and pulmonary vasculature.

\section{Analysis of left ventricular function}

The microcomputer calculated and displayed the count over the region of interest during one cardiac cycle at $50 \mathrm{msec}$ intervals throughout the exercise test. As previously described 28 the left ventricular ejection fraction was calculated using $70 \%$ of the end-diastolic counts as the background activity as follows:

$$
\mathrm{EF}=\mathrm{SC} /[0.3 \times \mathrm{EDC}]
$$

where $\mathrm{EF}=$ ejection fraction; $\mathrm{SC}=$ stroke counts (end-diastolic counts minus end-systo- 
Anaerobic threshold

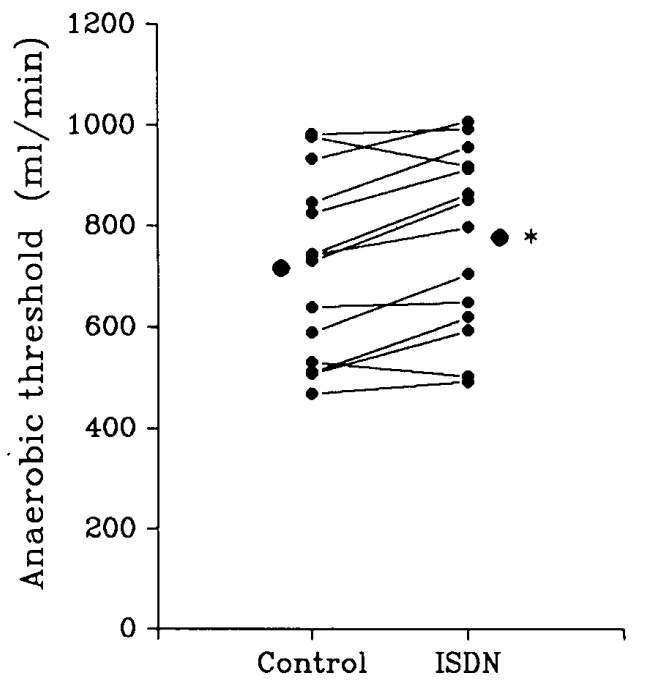

Peak $\dot{\mathrm{VO}}_{2}$

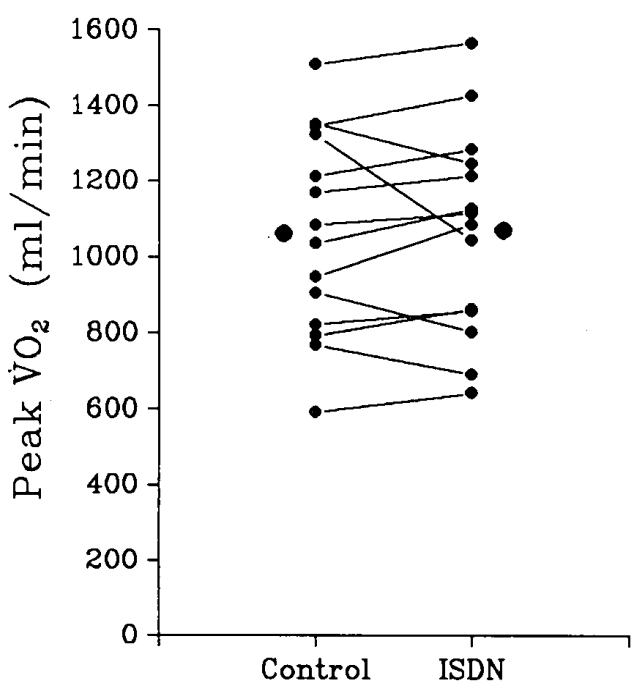

Fig.1. Effects of isosorbide dinitrate (ISDN) on the anaerobic threshold and peak oxygen uptake (peak $\dot{\mathrm{VO}}_{2}$ ). Large circles represent mean values. Isosorbide dinitrate increased the anaerobic threshold. ${ }^{*} \mathrm{p}<0.01 \mathrm{vs}$. control data.
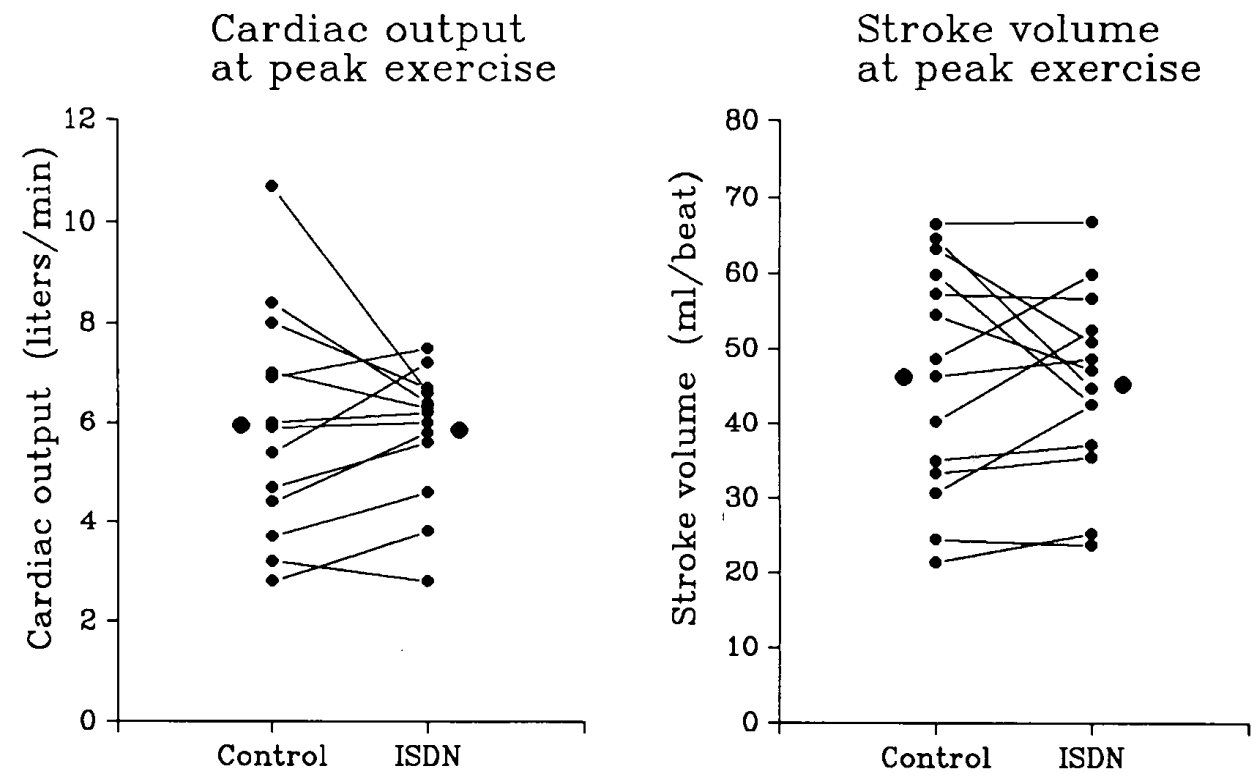

Fig.2. Effects of isosorbide dinitrate (ISDN) on cardiac output and stroke volume at peak exercise. Large circles represent mean values. Isosorbide dinitrate did not change either cardiac output or stroke volume.

lic counts); EDC $=$ end-diastolic counts.

Stroke volume at rest was calculated from the cardiac output measured by the dye dilution method, and was used to calculate absolute values of stroke volume from the ejection fraction derived by the radioactive counting technique. End-diastolic volume and end-systolic volume were calculated as follows:

$$
\mathrm{EDV}=\mathrm{SV} / \mathrm{EF} ; \mathrm{ESV}=\mathrm{EDV}-\mathrm{SV}
$$

where $\mathrm{EDV}=$ end-diastolic volume; $\mathrm{ESV}=$ end-systolic volume; SV=stroke volume.

Stroke volume, end-diastolic volume, and end-systolic volume during exercise were calculated from stroke counts, end-diastolic counts, and end-systolic counts by measuring 

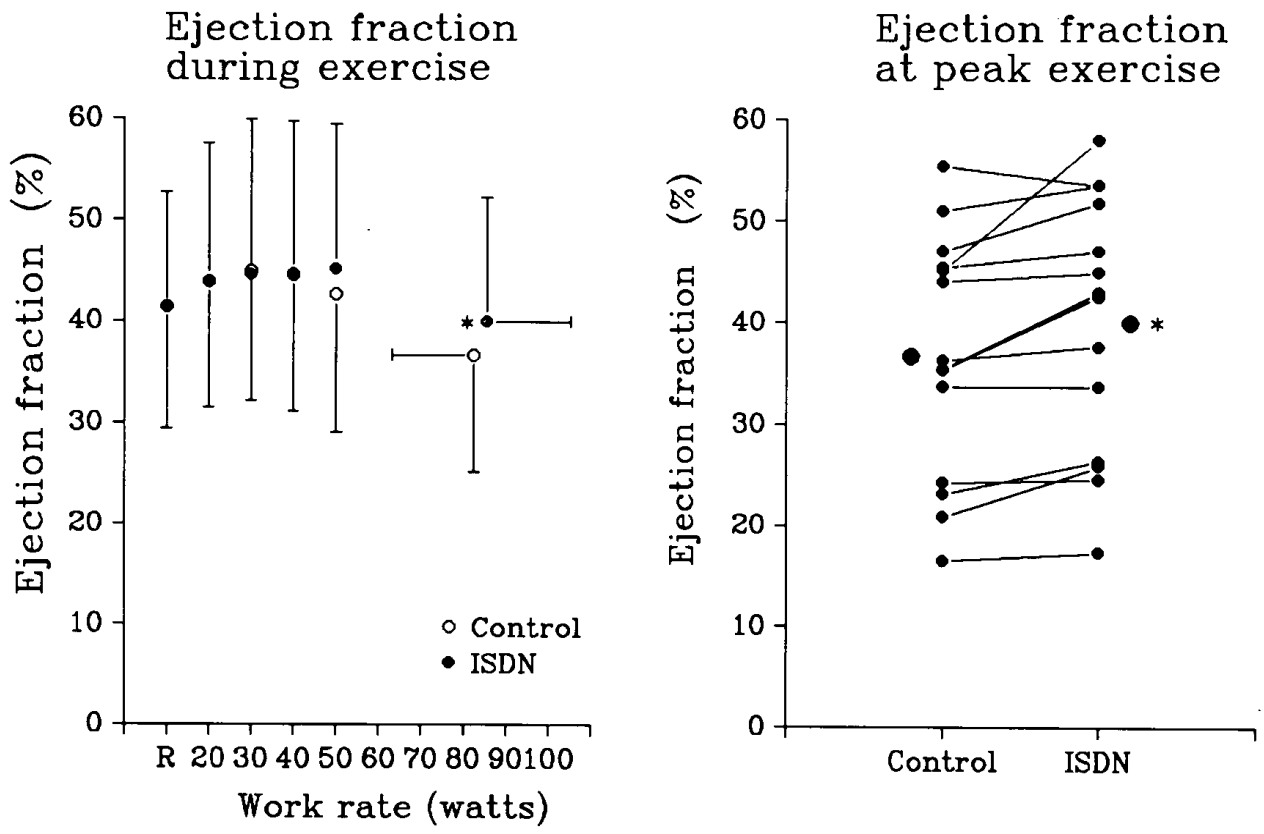

Fig.3. Effects of isosorbide dinitrate (ISDN) on ejection fraction during exercise (left panel) and at peak exercise (right panel). Large circles represent mean values (right panel). $\mathrm{R}=$ rest. Values are mean $\pm \mathrm{SD}$ (left panel). ${ }^{*} \mathrm{p}<0.05$ vs. control data.

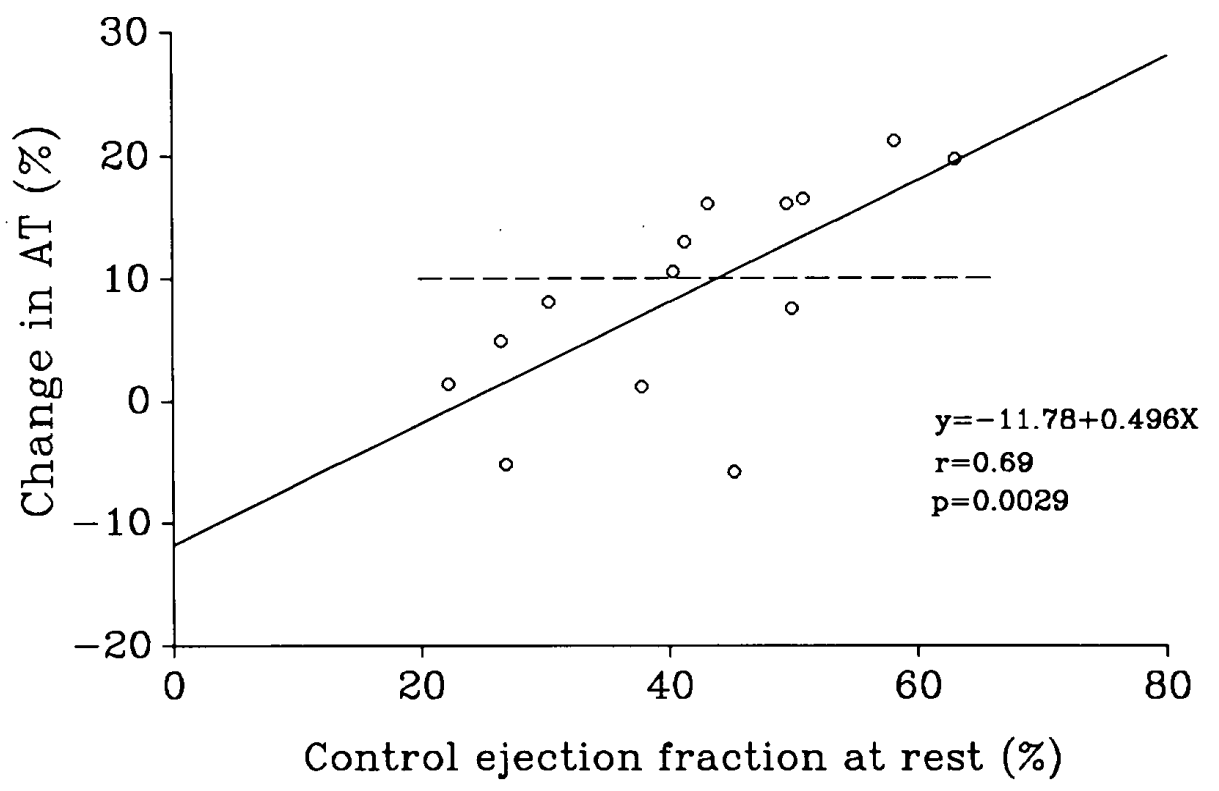

Fig.4. Relationship between the percent change of the anaerobic threshold ( $\underline{\mathrm{AT}})$ and ejection fraction of the control data obtained at rest. Dashed line represents $10 \%$ change of the anaerobic threshold.

the change of these parameters from rest. After the test, ejection fraction, stroke volume, end-diastolic volume, end-systolic volume, and cardiac output throughout the test were determined using 10 second averaging.

\section{Statistical methods}

All data were presented as mean $\pm \mathrm{SD}$. The paired t-test was used to compare the resting and peak exercise hemodynamic data between the control test and that after administration of isosorbide dinitrate. The com-

Japanese Circulation Journal Vol. 54, December 1990 
TABLE II HEMODYNAMIC DATA AND OXYGEN UPTAKE OF EACH GROUP AT REST

\begin{tabular}{|c|c|c|c|c|}
\hline & \multicolumn{2}{|c|}{ Group $1(n=7)$} & \multicolumn{2}{|c|}{ Group $2(n=7)$} \\
\hline & Control & After ISDN & Control & After ISDN \\
\hline $\begin{array}{l}\text { Heart rate } \\
\quad(\text { bpm })\end{array}$ & $72.8 \pm 10.4$ & $80.9 \pm 13.6^{*}$ & $80.7 \pm 12.5$ & $84.3 \pm 8.5$ \\
\hline $\begin{array}{l}\text { Systolic blood } \\
\text { pressure }(\mathrm{mmHg})\end{array}$ & $142.9 \pm 15.5$ & $135.1 \pm 24.6$ & $141.7 \pm 22.5$ & $128.7 \pm 24.1^{* *}$ \\
\hline $\begin{array}{l}\text { Diastolic blood } \\
\quad \text { pressure }(\mathrm{mmHg})\end{array}$ & $77.3 \pm 6.0$ & $75.3 \pm 8.2$ & $78.7 \pm 7.9$ & $77.3 \pm 9.8$ \\
\hline $\begin{array}{l}\text { Ejection fraction } \\
(\%)\end{array}$ & $49.4 \pm 8.0$ & $49.2 \pm 8.3$ & $33.5 \pm 10.0 \#$ & $33.4 \pm 8.4$ \\
\hline $\begin{array}{l}\text { Stroke volume } \\
\quad(\text { ml/beat })\end{array}$ & $52.9 \pm 12.4$ & $47.6 \pm 11.3$ & $45.4 \pm 14.8$ & $41.0 \pm 7.5$ \\
\hline $\begin{array}{l}\text { Cardiac output } \\
\quad(\text { l/min })\end{array}$ & $3.8 \pm 0.8$ & $3.7 \pm 0.6$ & $3.6 \pm 1.1$ & $3.4 \pm 0.6$ \\
\hline $\begin{array}{l}\text { Oxygen uptake } \\
(\mathrm{ml} / \mathrm{min})\end{array}$ & $208.6 \pm 26.4$ & $219.3 \pm 24.2$ & $235.6 \pm 60.9$ & $223.9 \pm 54.8$ \\
\hline
\end{tabular}

Data are mean $\pm S D$. ISDN $=$ isosorbide dinitrate.

${ }^{*} p<0.05$ vs. corresponding control data. ${ }^{* *} p<0.01$ vs. corresponding control data.

$\# p<0.05$ vs. control data of group 1 .

TABLE III WORK RATE, HEMODYNAMIC DATA AND OXYGEN UPTAKE OF EACH GROUP AT PEAK EXERCISE

\begin{tabular}{|c|c|c|c|c|}
\hline & \multicolumn{2}{|c|}{ Group $1(n=7)$} & \multicolumn{2}{|c|}{ Group $2(n=7)$} \\
\hline & Control & After ISDN & Control & After ISDN \\
\hline $\begin{array}{l}\text { Work rate } \\
\text { (watts) }\end{array}$ & $84.0 \pm 13.6$ & $86.4 \pm 12.8$ & $80.9 \pm 23.7$ & $84.4 \pm 25.1$ \\
\hline $\begin{array}{l}\text { Heart rate } \\
\quad(\text { bpm })\end{array}$ & $129.1 \pm 24.8$ & $132.0 \pm 22.3$ & $129.5 \pm 17.6$ & $130.6 \pm 19.2$ \\
\hline $\begin{array}{l}\text { Systolic blood } \\
\quad \text { pressure }(\mathrm{mmHg})\end{array}$ & $191.6 \pm 20.3$ & $196.7 \pm 30.9$ & $184.1 \pm 37.7$ & $173.7 \pm 41.5$ \\
\hline $\begin{array}{l}\text { Diastolic blood } \\
\quad \text { pressure }(\mathrm{mmHg})\end{array}$ & $93.4 \pm 5.9$ & $87.0 \pm 14.9$ & $85.9 \pm 11.0$ & $88.7 \pm 16.6$ \\
\hline $\begin{array}{l}\text { Ejection fraction } \\
(\%)\end{array}$ & $41.6 \pm 6.3$ & $46.7 \pm 7.6^{*}$ & $31.7 \pm 13.4$ & $33.1 \pm 12.3$ \\
\hline $\begin{array}{l}\text { Stroke volume } \\
\quad(\text { mllbeat })\end{array}$ & $48.6 \pm 8.8$ & $48.9 \pm 7.7$ & $43.7 \pm 18.7$ & $41.5 \pm 13.8$ \\
\hline $\begin{array}{l}\text { Cardiac output } \\
\quad(\text { l/min })\end{array}$ & $6.2 \pm 1.2$ & $6.3 \pm 0.4$ & $5.7 \pm 2.7$ & $5.4 \pm 1.6$ \\
\hline $\begin{array}{l}\text { Oxygen uptake } \\
\text { (mll/min) }\end{array}$ & $1045.3 \pm 175.6$ & $1071.9 \pm 167.4$ & $1074.4 \pm 321.4$ & $1060.3 \pm 329.7$ \\
\hline
\end{tabular}

Data are mean $\pm S D$. ISDN $=$ isosorbide dinitrate.

${ }^{*} p<0.05$ vs. corresponding control data.

parison of the anaerobic threshold of the control test and that after isosorbide dinitrate was also made by paired t-test. Comparisons of the control data at rest between group 1 and group 2 were made using the unpaired t-test. Linear regression analysis was used to correlate the resting ejection fraction of the control test with the percentage change of the anaerobic threshold. The significance level was set at $\mathrm{p}<0.05$. 
Group 1

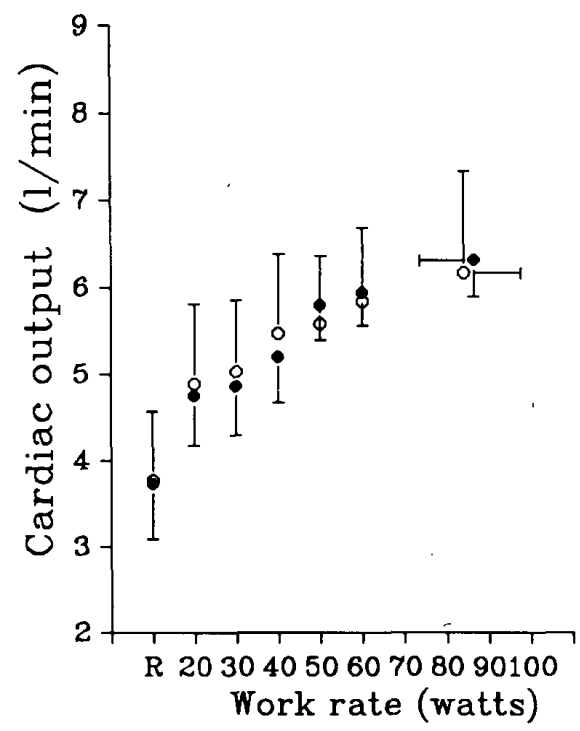

Group 2

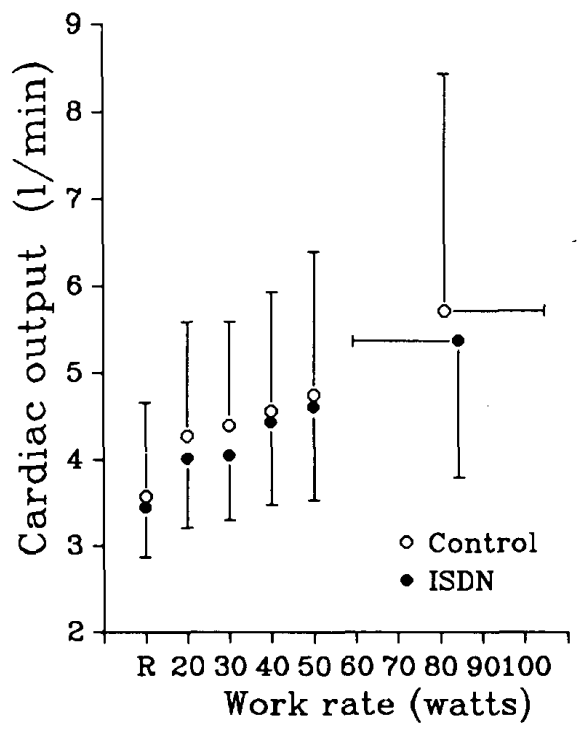

Fig.5. Cardiac output at rest $(\mathrm{R})$ and during the incremental exercise test. Values are mean $\pm \mathrm{SD}$. Although not statistically significant, cardiac output tended to decrease after isosorbide dinitrate (ISDN) for group 2, while it tended to increase during moderate to high intensity exercise for group 1.

\section{Group 1}

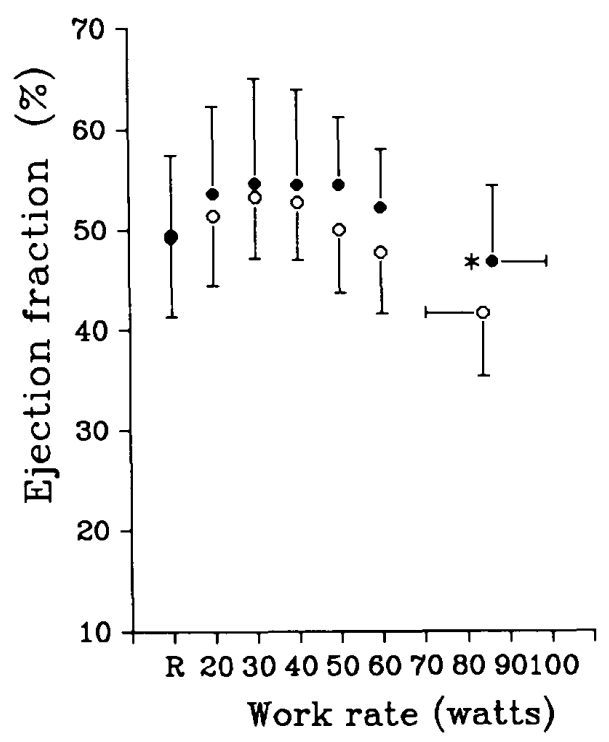

Group 2

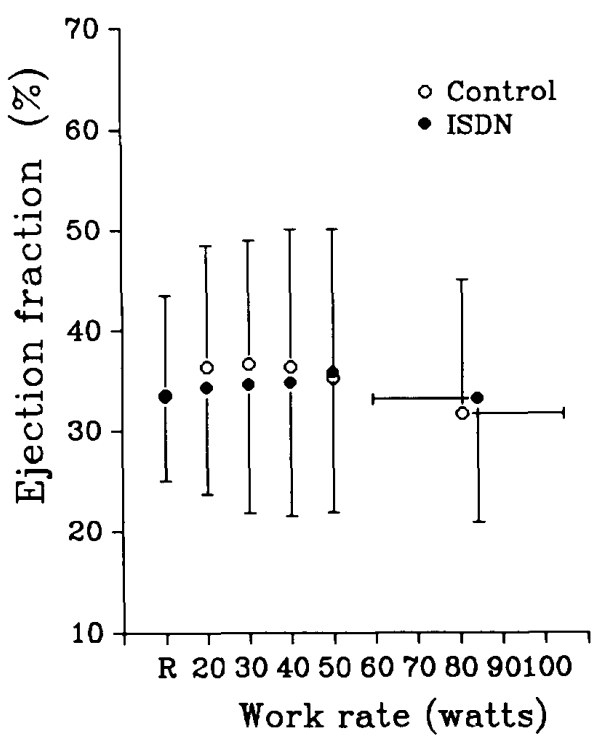

Fig.6. Ejection fraction at rest $(\mathrm{R})$ and during the incremental exercise test. Values are mean \pm SD. Isosorbide dinitrate (ISDN) increased ejection fraction during exercise for group 1. Ejection fraction of group 2 did not change after isosorbide dinitrate, and remained at low levels during exercise. ${ }^{*} \mathrm{p}<0.05$ vs. corresponding control data.

\section{RESULTS}

Isosorbide dinitrate did not improve cardiac output $(3.7 \pm 1.0$ vs. $3.6 \pm 0.6 \mathrm{l} / \mathrm{min})$, ejection fraction $(41.5 \pm 12.1$ vs. $41.3 \pm$ $11.5 \%)$, or stroke volume $(49.1 \pm 14.2$ vs.
$44.3 \pm 10.1 \mathrm{ml} /$ beat) at rest. Maximum work rate after isosorbide dinitrate was $85.4 \pm 19.9$ $\mathrm{W}$, which was not significantly different from control data $(82.4 \pm 19.4 \mathrm{~W})$. Fig. 1 shows the anaerobic threshold and peak $\mathrm{VO}_{2}$ of the control test and after administration of $5 \mathrm{mg}$ 
isosorbide dinitrate. The anaerobic threshold was easily determined in all the subjects by respiratory gas measurements. The mean value of the anaerobic threshold for the control test was $715.4 \pm 172.9 \mathrm{ml} / \mathrm{min}$. After isosorbide dinitrate, the anaerobic threshold significantly increased to $774.9 \pm 173.5 \mathrm{ml} /$ $\min (\mathrm{p}<0.01)$. However, peak $\mathrm{VO}_{2}$ of the control test and that after isosorbide dinitrate were $1059.9 \pm 259.4 \mathrm{ml} / \mathrm{min}$ and $1066.1 \pm 261.5 \mathrm{ml} / \mathrm{min}$, respectively, which was not statistically different. Fig. 2 shows the effect of isosorbide dinitrate on cardiac output and stroke volume at peak exercise. Isosorbide dinitrate did not change cardiac output $(5.9 \pm 2.1$ vs. $5.8 \pm 1.2 \mathrm{l} / \mathrm{min})$, nor stroke volume $(46.1 \pm 14.9$ vs. $45.2 \pm 11.8$ $\mathrm{ml} /$ beat) at peak exercise. However, as shown in Fig. 3, isosorbide dinitrate increased ejection fraction at peak exercise from $36.7 \pm 11.6$ to $39.9 \pm 12.3 \%(\mathrm{p}<0.05)$.

Fig. 4 shows the relationship between the percent change of the anaerobic threshold and the resting ejection fraction of the control test. The percent change of the anaerobic threshold correlated well to the resting ejection fraction $(y=-11.78+0.496 x, r=$ $0.69, \mathrm{p}=0.0029)$. This relationship suggested that isosorbide dinitrate had little effect on cardiac patients with low ejection fraction. To clarify the factors associated with an improvement in the anaerobic threshold after isosorbide dinitrate therapy, the subjects were divided into two groups according to the percentage change of the anaerobic threshold. In group 1 the change in the anaerobic threshold was 10 percent or greater, while in group 2 it was less than 10 percent.

While isosorbide dinitrate increased the anaerobic threshold of group 1 from $678.7 \pm 132.1 \mathrm{ml} / \mathrm{min}$ to $784.9 \pm 134.8 \mathrm{ml} / \mathrm{min}$ $(\mathrm{p}<0.001)$, the increase observed for the anaerobic threshold of group 2 was not significant (Table I). Table II shows the baseline characteristics of each group at rest: The resting ejection fraction of the control test was $33.5 \pm 10.0 \%$ for group 2 , significantly lower than group $1(49.4 \pm 8.0 \%, \mathrm{p}<0.05)$. After isosorbide dinitrate, heart rate at rest was significantly increased from $72.8 \pm 10.4$ to $80.9 \pm 13.6 \mathrm{bpm}(\mathrm{p}<0.05)$ for group 1 . For group 2, systolic blood pressure at rest was significantly decreased from $141.7 \pm 22.5$ to $128.7 \pm 24.1 \mathrm{mmHg}(\mathrm{p}<0.01)$. Table III shows the hemodynamic and $\mathrm{VO}_{2}$ data of each group at peak exercise. While maximum work rate did not change after isosorbide dinitrate for either group, ejection fraction at peak exercise significantly increased from $41.6 \pm 8.8 \%$ to $46.7 \pm 7.6 \% \quad(\mathrm{p}<0.05)$ for group 1.

Cardiac output during the exercise test tended to be lower and not to rise as readily in response to exercise with or without isosorbide dinitrate in group 2 as compared to group 1 (Fig. 5). Cardiac output of group 1 was higher between $50 \mathrm{~W}$ and maximum work rate after isosorbide dinitrate, compared to the control test, but this difference was not statistically significant.

Fig. 6 shows the ejection fraction change of both groups during exercise. For group 1, ejection fraction during exercise was higher after isosorbide dinitrate, especially for moderate to high intensity exercise. But ejection fraction of group 2 did not change after isosorbide dinitrate, and remained at low levels during exercise

Concentrations of isosorbide dinitrate, isosorbide-2-mononitrate, and isosorbide-5mononitrate measured just before the second exercise test were $10.8 \pm 5.0$, $14.8 \pm 8.6$, and $83.0 \pm 47.7 \mathrm{ng} / \mathrm{ml}$ for group 1 $(\mathrm{n}=4)$, and $7.8 \pm 3.8,8.2 \pm 6.8$, and $63.2 \pm$ $93.4 \mathrm{ng} / \mathrm{ml}$ for group $2(\mathrm{n}=5)$, respectively, the differences not being statistically significant.

\section{DISCUSSION}

Nitrates have been used widely in the treatment of acute and chronic heart failure due to left ventricular dysfunction $3^{30-32}$ The main actions of nitrates are to decrease left ventricular end-diastolic pressure and increase cardiac output 33 However, it is well known that indices of resting left ventricular performance in heart failure do not correlate with exercise capacity! $15,34,35$ Because exercise intolerance is a characteristic symptom of heart failure patients, the important therapeutic objective of nitrate therapy is to improve exercise capacity?

It has been suggested that anaerobic metabolism occurs during exercise when oxygen supply to the working muscles cannot be increased sufficiently to maintain aerobic 
metabolism. Therefore, the anaerobic threshold, which assesses the metabolic rate at which lactic acidosis occurs, can be used to identify noninvasively the severity of chronic heart failure ${ }^{15-18}$ The anaerobic threshold generally correlates well with the symptoms of heart failure, such as the New York Heart Association functional classification, and is thought to be a quantitative parameter. ${ }^{16}$ To determine the anaerobic threshold clearly, we employed $1 \mathrm{~W}$ incremental loading every 6 seconds (ramp pattern) for exercise testing, instead of a 3min incremental test, which has been commonly used to evaluate cardiac patients. We also used the $\mathrm{V}$-slope method ${ }^{25}$ to determine the anaerobic threshold point, because it is less affected by the ventilatory adjustment for metabolic acidosis than other gas exchange methods previously described.

A number of investigators have defined exercise capacity in cardiac patients as exercise duration, maximum work rate, or peak $\mathrm{VO}_{2}$. Consistent with previous reports $5,6,9$ isosorbide dinitrate did not increase maximum work rate, nor peak $\mathrm{VO}_{2}$. However, the anaerobic threshold was significantly improved by isosorbide dinitrate in this study. To our knowledge, this is the first report which describes the efficacy of isosorbide dinitrate by measuring the anaerobic threshold.

We divided the subjects into two groups according to the percentage change in the anaerobic threshold, in order to clarify how the anaerobic threshold was improved by isosorbide dinitrate. The ejection fraction and cardiac output responses of group 1 were fundamentally different from those of group 2. Patients of group 1 increased ejection fraction more during exercise after isosorbide dinitrate. An increased ejection fraction without an increase in stroke volume implies a relative reduction in end-diastolic volume and this would be consistent with the fall in pulmonary wedge pressure, which is the main action of isosorbide dinitrate.

Differences in hemodynamic response may also reflect differing etiologies of heart failure in the study subjects. Eight patients with coronary artery disease in the present study significantly increased ejection fraction at peak exercise from. $43.3 \pm 9.3$ to $47.2 \pm$ $9.2 \%$ as well as the anaerobic threshold
$(738.0 \pm 174.9$ to $800.3 \pm 163.0 \mathrm{ml} / \mathrm{min})$. Although the remaining six patients without documented coronary artery disease significantly improved the anaerobic threshold from $685.3 \pm 165.5$ to $741.0 \pm 181.0 \mathrm{ml} / \mathrm{min}$, the increase in ejection fraction at peak exercise was not significant $(27.8 \pm 7.7$ vs. $30.2 \pm 8.5 \%$ ). Most of the patients with coronary artery disease had ST segment depression during exercise, and there was a tendency for the onset of ST segment depression to occur at a later stage following isosorbide dinitrate administration. Therefore, increased ejection fraction may be due to the improvement in asymptomatic ischemia, as well as the reduction in preload.

The change in the anaerobic threshold was positively related to the change in the ejection fraction at peak exercise. Ejection fraction at this level seemed to be a sensitive index of the efficacy of vasodilators on cardiac patients during exercise, although the most important factor increasing exercise capacity is probably oxygen delivery to the working muscles, i.e., cardiac output. For this reason, we have to note that isosorbide dinitrate also increased cardiac output during moderate to maximum work rate exercise for group 1, although the change was not statistically significant because of the small number of subjects.

Franciosa et $\mathrm{al}^{6}$ reported that isosorbide dinitrate increased maximal oxygen consumption in heart failure patients without changing maximal exercise hemodynamics. Therefore, they suggested that the improvement in exercise capacity induced by isosorbide dinitrate is related to peripheral factors rather than a change in cardiac performance during exercise. Our results do not entirely contradict this opinion. Isosorbide dinitrate may have deflected flow to the working muscles without increasing cardiac output, and thus reduced lactate production. In the present study, the arterial-venous $\mathrm{O}_{2}$ difference ( $\mathrm{VO}_{2} /$ cardiac output) at rest of group 1 was $5.7 \pm 1.1 \mathrm{ml} / \mathrm{dl}$ for the control test, and $6.1 \pm 1.3 \mathrm{ml} / \mathrm{dl}$ after isosorbide dinitrate. Although the change was not statistically significant, arterial-venous $\mathrm{O}_{2}$ difference during exercise also tended to be greater after isosorbide dinitrate $(11.8 \pm 2.1$ vs. $13.1 \pm 1.7$ $\mathrm{ml} / \mathrm{dl}$ at the anaerobic threshold). These results may support the hypothesis that 
peripheral factors are affected by isosorbide dinitrate. However, some improvement in cardiac performance during exercise may also be important for improved anaerobic threshold.

In the present study; $5 \mathrm{mg}$ of isosorbide dinitrate was administered to all the subjects, because our subjects did not include patients with severe congestive heart failure. Given the minor changes in resting heart rate and blood pressure, it appears that this dose may have been too small for our subjects and may account for the lack of significant differences in some of the variables measured, although pharmacologic levels were achieved.

Kulick and his colleagues ${ }^{36}$ reported that resistance to oral isosorbide dinitrate is common in patients with severe, chronic heart failure. Our results also suggest that acute administration of isosorbide dinitrate has little effect on exercise capacity in cardiac patients with low resting ejection fraction.

In this study, left ventricular function was evaluated with the computerized cadmium telluride detector which allows beat-to-beat assessment of the radionuclide time-activity curve. This device has also been shown to evaluate accurately left ventricular function in patients with atrial fibrillation ${ }^{37}$ However, there are potential limitations which should be considered in the evaluation of the data obtained by this technique. Although background activity might increase with increased work rate during exercise in patients with severe congestive heart failure, we used a fixed percent of end-diastolic counts as background activity to calculate ejection fraction, which could lead to underestimation of exercise cardiac output and stroke volume. The constant position of the cadmium telluride detector over the right anterior chest could lead to errors in calculated values if there were a change in cardiac position during exercise. However, positional changes would be unlikely to result in a systematic error, and a change in background activity, which seems to be small in patients with mild-tomoderate left ventricular dysfunction 28 would have only a minor effect on the absolute value of indices of left ventricular function during exercise.

Isosorbide dinitrate raised the anaerobic threshold in patients with mild to moderate reductions in ejection fraction. This might allow these patients a higher level of sustainable activity before becoming acidotic and fatigued. This improvement would not be detected from measurements of exercise duration or peak $\dot{\mathrm{VO}}_{2}$ alone.

\section{Acknowledgment}

We thank Thomas J. Barstow, PhD for his critical comments, and Kathy E. Sietsema, MD and Karlman Wasserman, MD, PhD of Harbor-UCLA Medical Center for their thoughtful review of this manuscript.

\section{REFERENCES}

1. MILLER RR, VISMARA LA, ZELIS R, AMSTERDAM EA, MASON DT: Clinical use of sodium nitroprusside in chronic ischemic heart disease. Effects on peripheral vascular resistance and venous tone and on ventricular volume, pump and mechanical performance. Circulation 51: 328-336, 1975

2. FRANCIOSA JA, BLANK RC, COHN JN: Nitrate effects on cardiac output and left ventricular outflow resistance in chronic congestive heart failure. Am J Med 64: 207-213, 1978

3. RUBIN SA, CHATTERJEE K, GELBERG HJ, PORTS TA, BRUNDAGE BH, PARMLEY WW: Paradox of improved exercise but not resting hemodynamics with short-term prazosin in chronic heart failure. Am J Cardiol 43: 810-815, 1979

4. WILSON JR, UNTEREKER W, HIRSHFELD J, FERRARO N: Effects of isosorbide dinitrate and hydralazine on regional metabolic responses to arm exercise in patients with heart failure. Am J Cardiol 48: $934-938,1981$

5. FRANCIOSA JA, COHN JN: Effect of isosorbide dinitrate on response to submaximal and maximal exercise in patients with congestive heart failure. Am J Cardiol 43: 1009-1014, 1979

6. FRANCIOSA JA, GOLDSMITH SR, COHN JN: Contrasting immediate and long-term effects of isosorbide dinitrate on exercise capacity in congestive heart failure. Am J Med 69: 559-566, 1980

7. STEPHENS JD, DYMOND DS, SPURRELL RAJ: Radionuclide and hemodynamic assessment of left ventricular functional reserve in patients with left ventricular aneurysm and congestive cardiac failure: Response to exercise stress and isosorbide dinitrate. Circulation 61: 536-542, 1980

8. WILSON JR, FERRARO N: Effect of isosorbide dinitrate on submaximal exercise capacity of patients with chronic left ventricular failure. Chest 82: 701-704, 1982

9. LEIER CV, HUSS P, MAGORIEN RD, UNVERFERTH DV: Improved exercise capacity and differing arterial and venous tolerance during chronic isosorbide dinitrate therapy for congestive heart failure. Circulation 67: 817-822, 1983

10. SCHARTL M, DOUGHERTY C, RUTSCH W, SCHMUTZLER H: Hemodynamic effects of molsidomine, isosorbide dinitrate, and nifedipine at

Japanese Circulation Journal Vol. 54, December 1990 
rest and during exercise. Am Heart $J$ 109: 649-653, 1985

11. JANSEN W, MEYER L, TAUCHERT M: Acute effect of various doses of isosorbide-5-mononitrate on hemodynamic and exercise performance in coronary artery disease. Am J Cardiol 61: 31E35E, 1988

12. PARKER JO, FERRELL B, LAHEY KA, MOE G: Effect of intervals between doses on the development of tolerance to isosorbide dinitrate. $N$ Engl J Med 316: 1440-1444, 1987

13. RUDOLPH W, DIRSCHINGER J, REINIGER G, BEYERLE A, HALL D: When does nitrate tolerance develop? What dosages and which intervals are necessary to ensure maintained effectiveness? Eur Heart J 9 (Suppl A): 63-72, 1988

14. WASSERMAN K: New concepts in assessing cardiovascular function. Circulation 78: 1060-1071, 1988

15. WEBER KT, KINASEWITZ GT, JANICKI JS, FISHMAN AP: Oxygen utilization and ventilation during exercise in patients with chronic cardiac failure. Circulation 65: 1213-1223, 1982

16. MATSUMURA N, NISHIJIMA H, KOJIMA S, HASHIMOTO F, MINAMI M, YASUDA H: Determination of anaerobic threshold for assessment of functional state in patients with chronic heart failure. Circulation 68: $360-367,1983$

17. WEBER KT, JANICKI JS: Lactate production during maximal and submaximal exercise in patients with chronic heart failure. $J$ Am Coll Cardiol 6: $717-724,1985$

18. OPASICH C, COBELLI F, RICCARDI G, AQUILANI R, MARTINI AD, SPECCHIA G: Applicability of the anaerobic threshold in patients with previous myocardial infarction. Adv Cardiol 35: $100-107,1986$

19. NEMANICH JW, SHURMAN AJ, ROSSEN JD, KREMSER C, DAVIS F, RAJFER SI: Effects of long-term therapy with oral piroximone on resting hemodynamics, peak aerobic capacity, and the anaerobic threshold in patients with heart failure. $J$ Cardiovasc Pharmacol 10: 580-588, 1987

20. ATWOOD JE, MYERS JN, SULLIVAN MJ, FORBES SM, PEWEN WF, FROELICHER VF: Diltiazem and exercise performance in patients with chronic atrial fibrillation. Chest 92: 20-25, 1988

21. WAGNER HN, RIGO P, BAXTER RH, ALDERSON PO, DOUGLASS KH, HOUSHOLDER DF: Monitoring ventricular function at rest and during exercise with a nonimaging nuclear detector. Am J Cardiol 43: 975-979, 1979

22. UPTON MT, RERYCH SK, NEWMAN GE, PORT S, COBB FR, JONES RH: Detecting abnormalities in left ventricular function during exercise before angina and ST-segment depression. Circulation 62: 341-349, 1980

23. TAMAKI N, YASUDA T, MOORE RH, GILL JB, BOUCHER CA, HUTTER AM, GOLD HK, STRAUSS HW: Continuous monitoring of left ventricular function by an ambulatory radionuclide detector in patients with coronary artery disease. $J$ Am Coll Cardiol 12: 669-679, 1988

24. KINSMAN JM, MOORE JW, HAMILTON WF: Studies on the circulation; I. Injection method: Physical and mathematical considerations. Am J Physiol 89: 322-330, 1929

25. BEAVER WL, WASSERMAN K, WHIPP BJ: A new method for detecting anaerobic threshold by gas exchange. J Appl Physiol 60: 2020-2027, 1986

26. WASSERMAN K, WHIPP BJ: Exercise physiology in health and disease. Am Rev Respir Dis 112: 219-249, 1975

27. WASSERMAN K: The anaerobic threshold measurement to evaluate exercise performance. Am Rev Respir Dis 129 (Suppl): s35-s40, 1984

28. KOIKE A, ITOH H, TANIGUCHI K, HIROE $\mathrm{M}$ : Detecting abnormalities in left ventricular function during exercise by respiratory measurement. Circulation 80: 1737-1746, 1989

29. BERGER HJ, DAVIES RA, BATSFORD WP, HOFFER PB, GOTTSCHALK A, ZARET BL: Beat-to-beat left ventricular performance assessed from the equilibrium cardiac blood pool using a computerized nuclear probe. Circulation 63: 133142,1981

30. GRAY R, CHATTERJEE K, VYDEN JK, GANZ W, FORRESTER JS, SWAN HJC: Hemodynamic and metabolic effects of isosorbide dinitrate in chronic congestive heart failure. $\mathrm{Am}$ Heart J 90: 346-352, 1975

31. WILLIAMS DO, BOMMER WJ, MILLER RR, AMSTERDAM EA, MASON DT: Hemodynamic assessment of oral peripheral vasodilator therapy in chronic congestive heart failure: Prolonged effectiveness of isosorbide dinitrate. Am J Cardiol 39: 84-90, 1977

32. FRANCIOSA JA, NORDSTROM LA, COHN JN: Nitrate therapy for congestive heart failure. JAMA 240: 443-446, 1978

33. FRANCIOSA JA, PIERPONT G: Cardiovascular clinical pharmacology of impedance reducing agents. J Chron Dis 34: 341-352, 1981

34. FRANCIOSA JA, PARK M, LEVINE TB: Lack of correlation between exercise capacity and indexes of resting left ventricular performance in heart failure. Am J Cardiol 47: 33-39, 1981

35. WEBER KT, JANICKI JS: Cardiopulmonary exercise testing for evaluation of chronic cardiac failure. Am J Cardiol 55: 22A-31A, 1985

36. KULICK D, ROTH A, McINTOSH N, RAHIMTOOLA SH, ELKAYAM U: Resistance to isosorbide dinitrate in patients with severe chronic heart failure: Incidence and attempt at hemodynamic prediction. J Am Coll Cardiol 12: 1023-1028, 1988

37. SCHNEIDER J, BERGER HJ, SANDS MJ, LACHMAN AB, ZARET BL: Beat-to-beat left ventricular performance in atrial fibrillation: Radionuclide assessment with the computerized nuclear probe. Am J Cardiol 51: 1189-1195, 1983 